Journal of Applied Finance \& Banking, Vol. 12, No. 1, 2022, 1-26

ISSN: 1792-6580 (print version), 1792-6599(online)

https://doi.org/10.47260/jafb/1211

Scientific Press International Limited

\title{
Credit Resource Availability and Innovation Output: Evidence from Chinese Industrial Enterprises
}

\author{
Yuqiao Liu'
}

\begin{abstract}
This paper investigates the effect of credit availability on the number of industrial enterprises' patents from the perspective of financial geography, using the number of bank branches in the vicinity of industrial enterprises in China as a proxy variable. The number of patents is a proxy for the innovation output of an enterprise. The study finds that the higher availability of credit resources, represented by the number of bank branches in the vicinity, inhibits the innovation output of enterprises, and this inhibitory effect is more obvious in state-owned enterprises and large enterprises. Higher availability of credit resources leads industrial firms to fall more easily into the resource curse trap and thus fail to gain more innovative capabilities. This paper also provides a theoretical and data base for China's inability to complete industrial upgrading; it provides new evidence for the phenomenon of insufficient innovation capacity of industrial enterprises under China's rapid economic development in recent years; and it also provides a policy reference for financial supply reform.
\end{abstract}

Keywords: Availability of credit resources, Innovation output, Financial geography.

${ }^{1}$ University of California, Santa Barbara.

Article Info: Received: November 2, 2021. Revised: November 29, 2021.

Published online: December 9, 2021. 


\section{Introduction}

In the 21st century, although China is developing fast, the economic growth has not led to industrial upgrading and technological innovation. It has been more than 10 years since China and other countries such as the US, Europe and Japan adopted loose monetary policies to stimulate economic growth after the outbreak of the subprime mortgage crisis. The massive money supply and easy bank credit have not motivated enterprises to invest more in innovation and $R \& D$ (research and development) promoting the transformation. Many enterprises have used bank credit resources to expand their production capacity, investing blindly and without foresight. This has led to a situation of high leverage and overcapacity in many industries in China in recent years. The past decade of quantitative easing has also been witnessing to rapid expansion and increased competition in China's banking sector. In 2009, the China Banking Regulatory Commission (CBRC) issued the following guidelines, "Opinions on the Adjustment of Market Access Policy for Branches of Small and Medium-sized Commercial Banks". Easing institutional access for small and medium-sized banks. Commercial banks of all types have accelerated their nationwide presence, which has further exacerbated the uneven regional distribution of financial institutions and the availability of credit resources. In addition to the uneven distribution of financial resources geographically and spatially, there is also an uneven allocation in terms of enterprise ownership and size. State-owned enterprises (SOEs) and large enterprises become the stars who sought after by various financial institutions and are prone to financial resource overload. While private enterprises and small and medium-sized enterprises (SMEs) financing difficulties. Financing expensive problem has not been effectively alleviated. The established studies tend to look at the total amount of credit resources (Guiso et al,2004; Ji Zhihong, 2014) or in the regional level perspective (Xie Weimin \& Fang Hongxing, 2011, Tang Qingquan \& Wu Cen, 2015; Cai Jing $\&$ Dong Yan, 2016). However, little literature has examined the geographical structure of financial supply and the imbalance in the allocation of credit resources. The geographic structure of financial supply affects the availability and convenience of firms' access to external finance, which in turn affects micro-firms' investment decisions and innovation behavior. China is a financial system dominated by commercial banks and indirect financing. According to Yi Gang (2019): As of the end of 2018, the size of China's banking sector assets accounted for nearly 90 percent of the country's total financial sector assets. Credit resources are mainly allocated to various regions, industries and enterprises through commercial bank branches. The geographical proximity between banks and enterprises helps banks and enterprises, bankers and entrepreneurs to communicate and interact with each other, and obtain "soft information" related to enterprises. Reduce the information cost, transaction cost and supervision cost in the process of lending. This has led commercial banks to provide financial services with differential pricing based on geographical distance from the enterprise, prompting enterprises to choose external financing mainly from the neighboring banking 
institutions to obtain lending services. Therefore, the number of bank branches around an enterprise can, to some extent, represent the availability and convenience of credit resources for that enterprise or the region. The geographical proximity between banks and enterprises facilitates enterprises' access to external credit resources, which in turn alleviates the financing constraints faced by enterprises. (Degryse \& Ongena 2005; Agarwal \& Hauswald 2010; Zhang Shuangxu \& Du Xu 2019) Based on this, this paper intends to measure the availability of credit resources faced by enterprises from this perspective, and to analyze the above issues in more detail from the micro perspective of the number of bank branches and financial geographic structure.

Established studies tend to argue that the development of financial institutions and financial markets supports corporate innovation and facilitates the healthy development of enterprises (Benfratello et al., 2008; Xie Weimin \& Fang Hongxing, 2011; Tang Qingquan \& Wu Cen, 2015). However, with the continuous expansion of the number of commercial bank branches and the scale of assets in China, the leverage ratio of some enterprise sectors is rising, and the problem of overcapacity is becoming more and more serious, and over-indebtedness and over-investment have become a more common problem that restricts the healthy and sustainable development of enterprises in China. It is true that, credit resources are still scarce for most industrial enterprises. Many papers have also studied the relationship between financial resources and enterprise innovation from the perspective of the total supply of regional credit resources, and the results show that the abundance of regional credit resources is positively related to the innovation activities of regional enterprises (Yao Yaojun, 2012). However, there is a serious imbalance in the allocation of credit resources at the micro-firm level (Lu Zhengfei et al. 2015).

This paper uses the number of bank branches around industrial enterprises to measure the availability of credit resources faced by enterprises from the perspective of financial geography, and the number of patent applications and grants of industrial enterprises to indicate their innovation activities. This paper compared with the existing literature are as follows: First, unlike some scholars' findings that financial resources are conducive to firm innovation, this paper finds that the higher the availability of credit resources faced by a firm, the more innovation activity is inhibited. That is, there is a "resource curse" in the impact of bank credit availability on firms' innovation activities. This finding not only enriches the research on corporate innovation but also provides a new explanation for the widespread phenomenon of insufficient innovation in China's commercial bank-dominated financial system. Second, based on bank network data and the microscopic perspective of financial geography, the findings of this paper provide an empirical analysis of how the geographic structure of financial resource supply affects the number of patent applications and grants of industrial enterprises in transition economies and its underlying mechanisms. Most previous studies have adopted aggregate indicators at the provincial and municipal area level to measure the financial resources available to enterprises. This paper examines the availability and convenience of credit resources faced by firms from the micro perspective of bank- 
enterprise distance and financial geographic structure, and its impact on firms' innovation activities, enriching the research related to financial resources and firm innovation. Third, the research in this paper also provides a policy reference for the current financial supply reform. I find that the inhibitory effect of credit availability on corporate innovation is more pronounced among SOEs and large enterprises with financing advantages, which indicates that there is indeed a mismatch between property rights and scale of financial resources in China, and it is more of a structural imbalance.

\section{Theoretical analysis and hypothesis formulation}

\subsection{Financial geography and availability of credit resources}

Financial geography refers to the distribution and availability of financial resources at the geographic level. Financing opportunities for industrial firms depend not only on their own characteristics and the risk-reward of their projects but are also influenced by the relative geographic location of financial institutions. China's financial system is a typical system dominated by commercial banks. Compared to other countries dominated by commercial banks, China's total bank assets account for a much larger share of the country's total financial assets than in countries such as Japan and Germany. Therefore, the most important source of external financing available to industrial enterprises is credit from commercial banks. Under China's administrative and economic management system, the geographical and spatial distribution of commercial bank branches largely determines the availability and accessibility of external credit resources for firms. Due to China's administrative jurisdictional barriers and the main branch system of commercial banks that can inhibit the cross-regional flow of credit resources, the regional location and geographic distance between banks and enterprises remain the most important factors affecting enterprises' access to credit resources. The geographic distance between bank branches and industrial enterprises affects the access to credit resources in several ways. First, the geographical distance between banks and industrial enterprises increases communication and information exchange between the two parties, which helps banks to obtain soft information related to enterprises. Compared to hard information such as financial data, soft information as nonstandardized information can play a more important role in credit allocation by mitigating information asymmetry between banks and firms (Allen et al. 2005; Alessandrini et al. 2009; Hollander et al. 2016). Second, the closed geographical distance helps to reduce the information asymmetry between banks and firms. More, geographical proximity helps to reduce the transaction costs between banks and firms. Since transportation costs and time costs arising from geographical distance are the main components of transaction costs. To reduce the negative impact of transaction costs, banks tend to provide financial services to firms that are closer (Degryse \& Ongena, 2005; Agarwal \& Hauswald, 2010). Finally, proximity helps to reduce the risk and regulatory costs in financial services. Geographical distance increases banks' pre-lending review and post-lending administration costs for firms, 
which encourages banks to lend to firms that are closer. The above analysis shows that the geographical proximity of bank branches to industrial firms increases the availability of credit resources to firms.

\subsection{Availability of credit resources and firm innovation}

Existing studies have concluded that the development of the financial industry helps to alleviate the financing constraints of firms, which in turn effectively supports their innovative activities (Xie Weimin \& Fang Hongxing, 2011; Tang Qingquan \& $\mathrm{Wu}$ Cen, 2015). Industrial enterprises have limited endogenous financing, and external financial resources are the main source of funds for R\&D of enterprises. The bank branch-based financial geography positively affects industrial firms' innovation activities in two ways. First, from the perspective of financial resources and enterprise innovation, industrial enterprises need to introduce new equipment, new technologies, new talents in the process of innovation and R\&D continuously, therefore, this process requires large and continuous capital investment. However, due to the uncertainty, measurement and monitoring characteristics of industrial enterprises' innovation $R \& D$ activities, it is difficult to obtain external financial support. As a result, firms' innovation activities are more likely to be affected by financing constraints. Stable external financing resource is an important factor influencing firms' R\&D decisions. The proximity of banks to enterprises in terms of geographical distance can increase the availability and convenience of external credit resources for enterprises, which is conducive to alleviating the financing constraints faced by enterprises and promoting $R \& D$ investment of industrial enterprises. At the same time, the geographical proximity between banks and industrial enterprises also helps banks collect soft information related to enterprises' innovation activities more effectively and reduce information asymmetry, which helps banks select more promising $R \& D$ projects for financial support. Second, from the perspective of bank-business relationship and enterprise innovation: Based on the resource dependence theory, enterprises will obtain the required resources according to their own living environment (Pfeffer, 1978). Geographical proximity also motivates industrial firms to take the initiative to use this geo-relationship to increase communication with surrounding banking institutions, thus maintaining good relationships with banks and providing stable financial support for the innovation activities of industrial firms. Based on this, this paper proposes the following hypothesis:

H1a: Geographical proximity between industrial firms and banks can increase the credit resources availability to firms. Therefore, the more the number of bank branches around an enterprise, the more it is conducive to the availability of credit resources for the enterprise, which helps to promote the innovative activities of the enterprise. 
However, a large number of empirical studies have also found that commercial banks in China suffer from financial mismatch in the credit allocation process, which means property rights discrimination and scale discrimination. The liability side of commercial banks has rigid requirements, which leads to low risk tolerance of asset allocation on the asset side. Therefore, they prefer to allocate credit resources to state-owned enterprises which including local government financing platforms and large enterprises, while the innovation willingness and efficiency of such enterprises are low. This has also led to a weak support for regional and corporate innovation activities by the commercial bank-led financial system, which has not effectively contributed to the transformation and upgrading of the real economy (Zhang Jianhua et al. 2016). Therefore, the financial geography formed by bank branches could have a negative inhibiting effect on firms' innovation activities. Therefore, the financial geography of bank branches may also have a opposite inhibitory effect on firms' innovation activities, leading to the "Financial Resources Curse" for firms with higher availability of credit resources.

As the competition among commercial banks increases, state-owned or large enterprises are often highly preferred by all types and levels of banking institutions, which may lead to some enterprises obtaining more credit resources than they need for their normal development and becoming over-indebted. Over-indebtedness of enterprises can restrain innovation through both internal and external factors: (1) internal factors are due to the "balance of risk" considerations of enterprise operation. As the level of indebtedness increases, the annual interest payment will gradually increase, and the financial risk of the enterprise will be enlarged. In order to balance the overall risk of enterprises and avoid debt default, enterprises tend to reduce $R \& D$ investment to reduce the financial risk caused by the uncertainty of R\&D activities. (2) External factors originate from the restrictions of creditors. Even if the industry enterprise's $R \& D$ innovation is successful, the bank as a creditor can only get fixed interest payment, but if the enterprise's fixed assets are higher, the more collateralized assets are available for credit investment, and the bank loan is more guaranteed to be repaid. Therefore, banks as creditors are more likely to "lobby" entrepreneurs to invest in fixed assets rather than in R\&D. Clearly, creditors discourage firms from innovating, and the higher the share of credit, the more pronounced this discouraging effect is. Further analysis shows that when the number of banking institutions around an enterprise increases, entrepreneurs of high-quality enterprises are easily pursued and lobbied by surrounding bank, which also tends to overconfidence of entrepreneurs, resulting in short-sightedness and irrational decisions, manifested in the blind expansion of enterprises and overestimation of future investment project returns (Heaton 2002). This leads to over-investment in productive projects and squeezes out funds for $R \& D$ and innovation. At the same time, when there are more bank branches around the industry enterprise, the abundant credit resources are not only an important support to help the enterprise expand rapidly and seize the market share of competitors, but also a cause of excessive investment and "resource dependence" of the enterprise's development path. As Richardson (2006) said, Abundant cash flow can make 
companies more prone to overinvestment. Rather than investing in $R \& D$ and innovation activities, which have long lead times and high uncertainty, industrial firms are more likely to invest in fixed assets and expand their scale, which is a lowrisk and quick-impact growth model, thus reducing the number of patents of industry enterprises. Accordingly, this paper proposes the following hypothesis:

H1b: The higher the number of bank branches around industrial enterprises and the higher the availability of credit resources, the more likely it is to trigger overindebtedness and over-investment in industrial enterprises, which in turn inhibits the number of patents of industry enterprises.

\subsection{Impact of property rights discrimination and size discrimination}

The relationship between credit availability and the number of patents of industry enterprises is also influenced by the characteristics of enterprises themselves. Compared with private enterprises and small enterprises, state-owned enterprises and large enterprises tend to obtain more credit support and are more likely to be "over-indebted" and "over-invested". State-owned enterprises have the advantage of property rights and scale, and their borrowings are considered as rigid assets with government credit backing and implicit guarantee, and therefore are more likely to be sought after by various banks. In addition, commercial banks' credit allocation also prefers collateralized loan mode, and some enterprises with larger assets and more collateralizable assets are more likely to be favored by banks. In contrast, private enterprises and SMEs lack the backing and implicit guarantee of state credit, have fewer collateralizable assets, and higher information asymmetry between banks and enterprises, which makes loans more risky and harder to get support from bank credit funds. This is also known as "property rights discrimination" and "scale discrimination" in the process of bank credit rationing (Liu, 2011). Second, the tenure and assessment of SOEs executives are similar to those of local officials, with short and uncertain tenure. Such makes them more likely to internalize the pursuit of short-term performance goals in their business decisions, which in turn leads to a preference for "quick success and quick profit", short-term and sloppy development mode in their investment decisions after obtaining financial resources. The firms will be more willing to adopt innovation-driven development strategies that are time-consuming and uncertain (Chen et al. 2015). Accordingly, this paper proposes the following hypothesis:

H2: The availability of credit resources, represented by the number of bank branches around the firm, has a more significant impact on the number of patents of state-owned enterprises and large enterprises than those of private enterprises and SMEs. 


\section{Data and empirical model}

\subsection{Data}

This paper takes industrial enterprises from 2006 to 2013 as the research sample, and the information on bank branches and their geographical locations used is obtained from the National China Stock Market \& Accounting Research Database. The data of address information of industrial enterprises is obtained from the database of industrial enterprises published by the China National Intellectual Property Administration (CNIPA). Combining the geographic location data of banks and industrial companies, a geographic coordinate matching system based on Baidu map API written in Python was used to obtain the number of bank branches around the offices of industrial companies. The financial data of industrial enterprises were obtained from the China National Intellectual Property Administration. After further eliminating the missing samples, the final sample of 258464 enterprises - annual observations were obtained.

\subsubsection{Availability of credit resources}

Based on Degryse \& Ongena's (2007) study, the availability of credit resources is measured by the number of bank branches in the vicinity of the enterprise's office. The linear distance is calculated by the latitude and longitude of the company's office and the latitude and longitude of the bank branches, and the number of bank branches (Bank3km, Bank5km) within $3 \mathrm{~km}$ and $5 \mathrm{~km}$ of the company's office is used as a measure.

\subsubsection{Innovation measurement}

The total number of patent applications (apply) and patents granted (grant) of industrial enterprises obtained from the State Intellectual Property Office is used as a measure of innovation capacity. The relationship between the availability of different credit resources and R\&D efficiency is obtained.

\subsubsection{Control variables}

The Firm-level control variables are shown below:

\begin{tabular}{|c|c|c|}
\hline Symbols & Explanation & Source \\
\hline Size & Logarithm of total assets at the end of the year & CNIPA \\
\hline Age & Year from the beginning of the business & CNIPA \\
\hline ROA & Return on total corporate assets & CNIPA \\
\hline Lever & $\begin{array}{c}\text { Corporate leverage, equals to ratio of year-end } \\
\text { total liabilities to yea-end total asset }\end{array}$ & CNIPA \\
\hline
\end{tabular}


The city-level control variables are shown below:

\begin{tabular}{|c|c|c|}
\hline Variables Symbols & Variables Explanation & Source \\
\hline $\ln ($ GDP capita $)$ & Logarithm of GDP per capita & China City Statistical Yearbook \\
\hline $\ln$ (Population) & $\begin{array}{c}\text { Logarithm of Total year-end } \\
\text { population of prefecture-level cities }\end{array}$ & China City Statistical Yearbook \\
\hline Loan & $\begin{array}{c}\text { RMB Loan Balance of Financial } \\
\text { Institutions Divided by GDP }\end{array}$ & China City Statistical Yearbook \\
\hline Industry & $\begin{array}{c}\text { General Fiscal Expenditure Divided } \\
\text { by General Fiscal Revenue }\end{array}$ & China City Statistical Yearbook \\
\hline FDI & $\begin{array}{c}\text { General Fiscal Expenditure Divided } \\
\text { by General Fiscal Revenue }\end{array}$ & China City Statistical Yearbook \\
\hline Wage & $\begin{array}{c}\text { Amount of Actual Foreign Capital } \\
\text { utilized divide by GDP }\end{array}$ & China City Statistical Yearbook \\
\hline & $\begin{array}{c}\text { Average Wage of On-The-Job } \\
\text { Employees }\end{array}$ & China City Statistical Yearbook \\
\hline
\end{tabular}

\subsection{Empirical model}

The main empirical model setup of this paper is as follows:

Innovation $_{i, c, t}=\beta_{0}+\beta_{1} \times$ Bank $_{i, c, t}+\beta_{2} \times X_{i, c, t}+\beta_{3} \times Z_{c, t}+\alpha_{i}+\mu_{c}+\gamma_{t}+\epsilon_{i, c, t}$

The number of bank branches around the firm is measured by the number of bank branches in the range of $3 \mathrm{~km}$ and $5 \mathrm{~km} \mathrm{Bank} 3 \mathrm{~km}_{i, c, t}, B_{a n k} 5 \mathrm{~km}_{i, c, t}$, respectively. $X_{i, c, t}$ denotes the firm-level control variables, and $Z_{c, t}$ represents the city-level control variables. Additionally, I control for control variables for firm fixed effect, city fixed effect and year fixed effect, and $\epsilon_{i, c, t}$ denotes the residuals of the model. In the choice of regression model, a panel fixed-effects model is used for the dependent variable of Innovation Variables (Innovation $_{i, c, t}$ ). The regressions are smoothed with dependent variable for continuous variables to exclude the effects of outliers.

\subsection{Descriptive statistics}

Table 1 presents the results of the descriptive statistics of the main research variables in this paper. As can be seen from the table, the mean values of $3 \mathrm{~km}$ and $5 \mathrm{~km}$ distance between industrial enterprises and banks are 10.53 and 14.26, respectively, while the standard deviations are 8.414 and 8.037, respectively. This indicates that there are significant differences in the availability of bank credit resources faced by enterprises between each other. In addition, the different levels of development between cities also affect the results. Cities with better development 
potential are more able to attract bank branches, while the innovation activities of industrial firms are also influenced by the level of economic development of the region where they are located. To overcome the possible influence of this factor, city-level control variables have been included in all regressions below.

Table 1: Descriptive statistics

\begin{tabular}{|c|c|c|c|c|c|c|c|c|}
\hline Variables & $\mathbf{N}$ & mean & Std & $\min$ & p25 & median & p75 & $\max$ \\
\hline Bank3km & 2809,000 & 10.53 & 8.414 & 0 & 2 & 8 & 21 & 21 \\
\hline Bank5km & 2809,000 & 14.26 & 8.037 & 0 & 6 & 21 & 21 & 21 \\
\hline $\ln (1+$ Applications $)$ & 2366,000 & 0.490 & 7.691 & 0 & 0 & 0 & 0 & 2784 \\
\hline $\ln (1+$ Grants $)$ & 2366,000 & 0.179 & 4.964 & 0 & 0 & 0 & 0 & 3319 \\
\hline $\begin{array}{c}\ln \\
\text { (1+Invention } \\
\text { Applications }) \\
\end{array}$ & 2366,000 & 0.220 & 3.086 & 0 & 0 & 0 & 0 & 1280 \\
\hline $\begin{array}{c}\ln \\
(1+\text { Invention Grants })\end{array}$ & 2366,000 & 0.122 & 4.559 & 0 & 0 & 0 & 0 & 3489 \\
\hline $\begin{array}{c}\text { ln } \\
(1+\text { Design } \\
\text { Applications })\end{array}$ & 2366,000 & 0.148 & 4.229 & 0 & 0 & 0 & 0 & 1151 \\
\hline $\begin{array}{c}\text { Ln } \\
(1+\text { Design Grants })\end{array}$ & 2366,000 & 0.0350 & 1.522 & 0 & 0 & 0 & 0 & 1352 \\
\hline $\begin{array}{c}\ln \\
(1+\text { Utility Model } \\
\text { Applications })\end{array}$ & 2366,000 & 0.122 & 3.458 & 0 & 0 & 0 & 0 & 2484 \\
\hline $\begin{array}{c}\text { Ln } \\
(1+\text { Utility Model } \\
\text { Grants }) \\
\end{array}$ & 2366,000 & 0.0250 & 1.931 & 0 & 0 & 0 & 0 & 1772 \\
\hline Size & 2366,000 & 10.17 & 1.436 & 7.360 & 9.134 & 10.03 & 11.04 & 14.42 \\
\hline Age & 2366,000 & 1.987 & 0.740 & 0 & 1.609 & 2.079 & 2.485 & 3.871 \\
\hline Lever & 1991,000 & 0.528 & 0.281 & 0.00900 & 0.308 & 0.538 & 0.749 & 1.201 \\
\hline$R O A$ & 1991,000 & 0.145 & 0.227 & -0.158 & 0.0130 & 0.0600 & 0.182 & 0.998 \\
\hline Fixed Asset & 1991,000 & 0.367 & 0.239 & 0.00400 & 0.169 & 0.331 & 0.534 & 0.936 \\
\hline Cash Flow & 2366,000 & 0.129 & 0.209 & -0.125 & 0.00200 & 0.0520 & 0.155 & 1.020 \\
\hline $\ln ($ GDP capita $)$ & 2366,000 & 10.56 & 0.680 & 8.924 & 10.08 & 10.60 & 11.06 & 12.13 \\
\hline $\ln ($ Population $)$ & 2366,000 & 6.149 & 0.524 & 4.651 & 5.836 & 6.257 & 6.540 & 7.057 \\
\hline Industry & 2366,000 & 0.522 & 0.0740 & 0.324 & 0.474 & 0.528 & 0.570 & 0.690 \\
\hline$F D I$ & 2366,000 & 0.0300 & 0.0230 & 0 & 0.0110 & 0.0250 & 0.0440 & 0.108 \\
\hline Imbalance & 2366,000 & 1.765 & 1.004 & 0.905 & 1.127 & 1.359 & 2.051 & 6.086 \\
\hline Loan & 2366,000 & 0.953 & 0.455 & 0.324 & 0.607 & 0.820 & 1.203 & 2.340 \\
\hline Wage & 2366,000 & 3.430 & 1.169 & 1.359 & 2.535 & 3.348 & 4.197 & 6.638 \\
\hline
\end{tabular}




\section{Empirical analysis}

\subsection{Main empirical regression results}

Table 2 reports the regression results of the availability of credit resources, measured by the number of bank branches around the firm, on the number of patent applications and the number of patents granted by industrial firms.

Columns (1) to (2) of Table 2 show the regression results of the number of patent applications for industrial enterprises. It is found that the coefficient of the availability of credit resources is negative regardless of the number of bank branches within $3 \mathrm{~km}$ and $5 \mathrm{~km}$ of the enterprise's office. The coefficient of the core explanatory variable Bank $3 \mathrm{~km}$ is -0.00196 , which indicates that an increase of one standard deviation 8.414 in the number of bank branches within $3 \mathrm{~km}$ is associated with a decrease of $1.649 \%$ in the number of patent applications, while a standard increase in the number of bank branches within $5 \mathrm{~km}$ is associated with a decrease of $1.318 \%$ in the number of patent applications. In columns (3) - (4) of Table 2, I regress the number of patents granted by industrial firms as the dependent variable and find similar results: the number of bank branches within $3 \mathrm{~km}$ and $5 \mathrm{~km}$ are both significantly reduce the total number of patents granted by industrial firms at the $1 \%$ significant level.

The coefficient of the explanatory variable Bank $3 \mathrm{~km}$ is -0.00144 , which means that the number of patents granted decreases by $1.212 \%$ when the number of bank branches within $3 \mathrm{~km}$ of the firm increases by one standard deviation 8.414 , and similarly the number of patent applications decreases by $0.989 \%$ when the number of bank branches within $5 \mathrm{~km}$ decreases by one standard deviation. 
Table 2: Regression result of baseline model

\begin{tabular}{|c|c|c|c|c|}
\hline & \multicolumn{2}{|c|}{ ln (1+Application) } & \multicolumn{2}{|c|}{$\ln (\underline{1+G r a n t)}$} \\
\hline & (1) & $(2)$ & (3) & (4) \\
\hline Variables & OLS & OLS & OLS & OLS \\
\hline \multirow[t]{2}{*}{ Bank3km } & $-0.00196 * * *$ & & $-0.00144 * * *$ & \\
\hline & $(7.70 e-05)$ & & $(5.47 e-05)$ & \\
\hline \multirow[t]{2}{*}{ Bank5km } & & $-0.00164 * * *$ & & $-0.00123 * * *$ \\
\hline & & $(8.03 \mathrm{e}-05)$ & & $(5.54 \mathrm{e}-05)$ \\
\hline \multirow[t]{2}{*}{ Size } & $0.0394 * * *$ & $0.0396^{* * *}$ & $0.0222 * * *$ & $0.0224 * * *$ \\
\hline & $(0.000721)$ & $(0.000721)$ & $(0.000507)$ & $(0.000508)$ \\
\hline \multirow[t]{2}{*}{ Age } & $-0.0149 * * *$ & $-0.0151 * * *$ & $-0.0269 * * *$ & $-0.0271 * * *$ \\
\hline & $(0.00119)$ & $(0.00119)$ & $(0.000866)$ & $(0.000866)$ \\
\hline \multirow[t]{2}{*}{ Lever } & $-3.75 e-05$ & $-3.84 e-05$ & -0.000199 & -0.000200 \\
\hline & $(0.000100)$ & $(0.000101)$ & $(0.000124)$ & $(0.000125)$ \\
\hline \multirow[t]{2}{*}{$R O A$} & $0.00334 * *$ & $0.00339 * *$ & $0.00554 * * *$ & $0.00558 * * *$ \\
\hline & $(0.00134)$ & $(0.00134)$ & $(0.00183)$ & $(0.00183)$ \\
\hline \multirow[t]{2}{*}{ Fixed Asset } & $-0.00873 * * *$ & $-0.00856 * * *$ & $-0.00733^{* * *}$ & $-0.00720 * * *$ \\
\hline & $(0.00201)$ & $(0.00201)$ & $(0.00133)$ & $(0.00133)$ \\
\hline \multirow[t]{2}{*}{ Cash Flow } & $-0.00432 * *$ & $-0.00439 * *$ & $-0.00738^{* * *}$ & $-0.00743^{* * *}$ \\
\hline & $(0.00178)$ & $(0.00178)$ & $(0.00243)$ & $(0.00244)$ \\
\hline \multirow[t]{2}{*}{$\ln ($ GDP capita $)$} & $-0.0330 * * *$ & $-0.0343^{* * *}$ & 0.00368 & 0.00278 \\
\hline & $(0.00318)$ & $(0.00318)$ & $(0.00259)$ & $(0.00260)$ \\
\hline \multirow[t]{2}{*}{$\ln ($ Population $)$} & $0.283 * * *$ & $0.281 * * *$ & $0.276^{* * *}$ & $0.275 * * *$ \\
\hline & $(0.0162)$ & $(0.0162)$ & $(0.0116)$ & $(0.0116)$ \\
\hline \multirow[t]{2}{*}{ Industry } & $-0.257 * * *$ & $-0.258 * * *$ & $-0.358 * * *$ & $-0.359 * * *$ \\
\hline & $(0.0155)$ & $(0.0155)$ & $(0.0114)$ & $(0.0114)$ \\
\hline \multirow[t]{2}{*}{$F D I$} & $-0.655 * * *$ & $-0.660 * * *$ & $-0.363 * * *$ & $-0.366 * * *$ \\
\hline & $(0.0365)$ & $(0.0365)$ & $(0.0244)$ & $(0.0244)$ \\
\hline \multirow[t]{2}{*}{ Imbalance } & 0.000550 & 0.000510 & $0.00161 * * *$ & $0.00158^{* * *}$ \\
\hline & $(0.000611)$ & $(0.000611)$ & $(0.000415)$ & $(0.000415)$ \\
\hline \multirow[t]{2}{*}{ Loan } & $0.0428 * * *$ & $0.0426 * * *$ & $0.0159 * * *$ & $0.0157 * * *$ \\
\hline & $(0.00241)$ & $(0.00241)$ & $(0.00165)$ & $(0.00165)$ \\
\hline \multirow[t]{2}{*}{ Wage } & $0.00142 * * *$ & $0.00144 * * *$ & $0.000934 * * *$ & $0.000948 * * *$ \\
\hline & $(0.000252)$ & $(0.000253)$ & $(0.000187)$ & $(0.000187)$ \\
\hline \multirow[t]{2}{*}{ Constant } & $-1.526 * * *$ & $-1.499 * * *$ & $-1.664 * * *$ & $-1.644 * * *$ \\
\hline & $(0.105)$ & $(0.105)$ & $(0.0784)$ & $(0.0784)$ \\
\hline Firm FE & Yes & Yes & Yes & Yes \\
\hline City FE & Yes & Yes & Yes & Yes \\
\hline Year FE & Yes & Yes & Yes & Yes \\
\hline No. Obs & $1,839,203$ & $1,839,203$ & $1,839,203$ & $1,839,203$ \\
\hline R-squared & 0.530 & 0.530 & 0.481 & 0.480 \\
\hline
\end{tabular}




\subsection{Empirical test on different types of patents}

Table 3 reports the regression results of the availability of credit resources measured by the number of bank branches around the enterprise on the number of invention patent applications, design patent applications, and new utility patent applications, respectively.

Columns (1) to (6) of Table 3 show the regression results of the number of patent applications for industrial enterprises. The data show that the regression coefficients of $3 \mathrm{~km}$ and $5 \mathrm{~km}$ banks around the office of the enterprise are significantly negative at the $1 \%$ level. First, the result in column (1)-(2) reveals that the coefficient of the core explanatory variable Bank $3 \mathrm{~km}$ is -0.000852 , which indicates that an increase of one standard deviation 8.414 in the number of bank branches within $3 \mathrm{~km}$ decreases the number of patent applications for inventions by about $0.717 \%$. Similarly, a one standard deviation change in the number of bank branches within $5 \mathrm{~km}$ will bring about a $0.579 \%$ decrease in the number of patent applications. Second, similar results can be obtained from column (3)-(4) in Table 2, where a one standard deviation increase in the number of bank branches in a $3 \mathrm{~km}$ range would result in a $0.264 \%$ decrease in the number of design patent applications, and a one standard deviation increase in the number of bank branches in a $5 \mathrm{~km}$ range would result in a $0.208 \%$ decrease in the number of design patent applications. Third, the coefficient of the core explanatory variable Bank $3 \mathrm{~km}$ is -0.00152 as shown in column (5)-(6), and a one standard deviation increase in the number of bank branches within $3 \mathrm{~km}$ which is 8.414 results in a decrease of about $1.278 \%$ in the number of utility model applications and $1.036 \%$ decrease in the number of utility model patent applications. 
Table 3: Regression results of different types of patent applications

\begin{tabular}{|c|c|c|c|c|c|c|}
\hline & \multicolumn{2}{|c|}{$\begin{array}{c}\ln \\
(1+\text { Invention Applications })\end{array}$} & \multicolumn{2}{|c|}{$\begin{array}{c}\ln \\
(1+\text { Design Applications })\end{array}$} & \multicolumn{2}{|c|}{$\begin{array}{c}\ln \\
(1+\text { Utility Model } \\
\text { Applications })\end{array}$} \\
\hline & (1) & (2) & (3) & (4) & (5) & $(6)$ \\
\hline Variables & OLS & OLS & OLS & OLS & OLS & OLS \\
\hline \multirow[t]{2}{*}{ Bank3km } & $-0.000852 * * *$ & & $-0.000314 * * *$ & & $-0.00152 * * *$ & \\
\hline & $(4.36 \mathrm{e}-05)$ & & $(4.15 \mathrm{e}-05)$ & & $(6.01 \mathrm{e}-05)$ & \\
\hline \multirow[t]{2}{*}{ bank5 $\mathrm{km}$} & & $-0.000721 * * *$ & & $-0.000259 * * *$ & & $-0.00129 * * *$ \\
\hline & & $(4.53 e-05)$ & & $(4.38 \mathrm{e}-05)$ & & $(6.16 \mathrm{e}-05)$ \\
\hline \multirow[t]{2}{*}{ Size } & $0.0183 * * *$ & $0.0184 * * *$ & 0.00893 *** & $0.00897 * * *$ & $0.0273 * * *$ & $0.0275 * * *$ \\
\hline & $(0.000412)$ & $(0.000412)$ & $(0.000399)$ & $(0.000400)$ & $(0.000551)$ & $(0.000551)$ \\
\hline \multirow[t]{2}{*}{ Age } & $-0.00989 * * *$ & $-0.01000 * * *$ & -0.000771 & -0.000815 & $-0.0120 * * *$ & $-0.0122 * * *$ \\
\hline & $(0.000702)$ & $(0.000702)$ & $(0.000635)$ & $(0.000636)$ & $(0.000917)$ & $(0.000917)$ \\
\hline \multirow[t]{2}{*}{ Lever } & $-4.37 e-05$ & $-4.41 e-05$ & $1.27 \mathrm{e}-05$ & $1.25 \mathrm{e}-05$ & $-3.89 \mathrm{e}-05$ & $-3.96 e-05$ \\
\hline & $(5.35 \mathrm{e}-05)$ & $(5.37 \mathrm{e}-05)$ & $(3.24 \mathrm{e}-05)$ & $(3.26 \mathrm{e}-05)$ & $(7.32 \mathrm{e}-05)$ & $(7.38 \mathrm{e}-05)$ \\
\hline \multirow[t]{2}{*}{$R O A$} & $0.00142 * *$ & $0.00144 * *$ & $0.000903 * *$ & $0.000913 * *$ & $0.00251 * *$ & $0.00255^{* *} *$ \\
\hline & $(0.000627)$ & $(0.000627)$ & $(0.000382)$ & $(0.000382)$ & $(0.000994)$ & $(0.000995)$ \\
\hline \multirow[t]{2}{*}{ Fixed Asset } & $-0.00328 * * *$ & $-0.00321 * * *$ & -0.00171 & -0.00168 & $-0.00530 * * *$ & $-0.00517 * * *$ \\
\hline & $(0.00111)$ & $(0.00111)$ & $(0.00110)$ & $(0.00110)$ & $(0.00151)$ & $(0.00151)$ \\
\hline \multirow[t]{2}{*}{ Cash Flow } & $-0.00183^{*} *$ & $-0.00186 * *$ & $-0.00117 * *$ & $-0.00118 * *$ & $-0.00325 * *$ & $-0.00331 * *$ \\
\hline & $(0.000834)$ & $(0.000835)$ & $(0.000509)$ & $(0.000509)$ & $(0.00132)$ & $(0.00132)$ \\
\hline \multirow[t]{2}{*}{$\ln ($ GDP capita $)$} & $-0.00544 * * *$ & $-0.00599 * * *$ & $-0.0128 * * *$ & $-0.0130 * * *$ & $-0.0258 * * *$ & $-0.0267 * * *$ \\
\hline & $(0.00184)$ & $(0.00184)$ & $(0.00184)$ & $(0.00184)$ & $(0.00250)$ & $(0.00250)$ \\
\hline \multirow[t]{2}{*}{$\ln$ (Population) } & $0.108 * * *$ & $0.107 * * *$ & $0.0343 * * *$ & $0.0340 * * *$ & $0.260 * * *$ & $0.259 * * *$ \\
\hline & $(0.00956)$ & $(0.00956)$ & $(0.00815)$ & $(0.00815)$ & $(0.0135)$ & \begin{tabular}{|l|}
$(0.0135)$ \\
\end{tabular} \\
\hline \multirow[t]{2}{*}{ Loan } & 0.00122 & 0.00115 & $0.0174 * * *$ & $0.0173 * * *$ & $0.0317 * * *$ & $0.0316^{* * *}$ \\
\hline & $(0.00126)$ & $(0.00126)$ & $(0.00144)$ & $(0.00144)$ & $(0.00183)$ & $(0.00183)$ \\
\hline \multirow[t]{2}{*}{ Industry } & $-0.156 * * *$ & $-0.157 * * *$ & $-0.0799 * * *$ & $-0.0801 * * *$ & $-0.160 * * *$ & $-0.161 * * *$ \\
\hline & $(0.00914)$ & $(0.00914)$ & $(0.00823)$ & $(0.00823)$ & $(0.0119)$ & $(0.0119)$ \\
\hline \multirow[t]{2}{*}{ Imbalance } & $2.03 e-05$ & $4.19 \mathrm{e}-06$ & 0.000127 & 0.000119 & $0.000692 *$ & 0.000664 \\
\hline & $(0.000343)$ & $(0.000343)$ & $(0.000359)$ & $(0.000359)$ & $(0.000417)$ & $(0.000417)$ \\
\hline \multirow[t]{2}{*}{$F D I$} & $-0.344 * * *$ & $-0.346 * * *$ & $-0.247 * * *$ & $-0.248 * * *$ & $-0.351 * * *$ & $-0.355 * * *$ \\
\hline & $(0.0220)$ & $(0.0220)$ & $(0.0199)$ & $(0.0199)$ & $(0.0271)$ & \begin{tabular}{|l|}
$(0.0271)$ \\
\end{tabular} \\
\hline \multirow[t]{2}{*}{ Wage } & $-8.17 \mathrm{e}-05$ & $-7.37 \mathrm{e}-05$ & $7.46 \mathrm{e}-05$ & $7.77 \mathrm{e}-05$ & $0.00147 * * *$ & $0.00148 * * *$ \\
\hline & $(9.62 \mathrm{e}-05)$ & $(9.62 \mathrm{e}-05)$ & $(0.000134)$ & $(0.000134)$ & $(0.000223)$ & $(0.000223)$ \\
\hline \multirow[t]{2}{*}{ Constant } & $-0.633 * * *$ & $-0.621 * * *$ & $-0.104 *$ & $-0.0994 *$ & $-1.442 * * *$ & $-1.421 * * *$ \\
\hline & $(0.0623)$ & $(0.0623)$ & $(0.0542)$ & $(0.0542)$ & $(0.0868)$ & \begin{tabular}{|l|}
$(0.0868)$ \\
\end{tabular} \\
\hline Firm FE & Yes & Yes & Yes & Yes & Yes & Yes \\
\hline City FE & Yes & Yes & Yes & Yes & Yes & Yes \\
\hline Year FE & Yes & Yes & Yes & Yes & Yes & Yes \\
\hline No. Obs & $1,839,203$ & $1,839,203$ & $1,839,203$ & $1,839,203$ & $1,839,203$ & $1,839,203$ \\
\hline R-squared & 0.502 & 0.502 & 0.443 & 0.443 & 0.507 & 0.507 \\
\hline
\end{tabular}


Table 4 reports the regression results of credit resource availability measured by the number of bank branches around the enterprise on the number of invention patents granted, the number of design patents granted, and the number of new utility patents granted, respectively.

Column (1)-(2) are interpreted similarly to the above table, the regression coefficients for $3 \mathrm{~km}, 5 \mathrm{~km}$ banks are negative at the $1 \%$ significant level. Columns (3) to (6) of Table 4 show the regression results for the number of patents granted to industrial enterprises. The data show that the regression coefficient is negative at the $1 \%$ significant level for $3 \mathrm{~km}$ and $5 \mathrm{~km}$ for the bank. By looking at the summary (1)-(6), for the number of $3 \mathrm{~km}$ banks, a one standard deviation increase decreases the number of patents granted, the number of design patents granted, and the number of new utility patents granted by $0.342 \%, 0.241 \%$, and $0.892 \%$, respectively. for the number of banks around $5 \mathrm{~km}$, a one standard deviation increase decreases the number of patents granted by $0.330 \%, 0.193 \%$, and $0.703 \%$ for the above three categories. For the number of banking institutions in $5 \mathrm{~km}$, an increase of one standard deviation decreases the number of patents granted by $0.330 \%, 0.193 \%$ and $0.703 \%$.

Based on the above statistics, it can be concluded that an increase in the number of banks around a company will suppress the number of patents granted by the company. The same conclusion can be drawn from Tables 2, 3 and 4, both in terms of the total number of patent applications and grants, and in terms of the classification of different types of patents: the higher the availability of credit resources, the more it inhibits the innovation activity of the firm, showing the resource curse of the availability of bank credit resources. This suggests that the number of bank branches in the vicinity of an enterprise does have an impact on the number of industrial patent applications and licenses, and thus hypothesis H1b is verified.

However, due to "ownership discrimination" and "size discrimination" issues in the allocation of credit resources, a large amount of credit resources is concentrated in state-owned enterprises (SOEs) and large enterprises, while private enterprises and Small and Medium Enterprises (SMEs) often face difficulties in financing, and the allocation of credit resources is polarized. The allocation of credit resources is polarized. I categorize the enterprises in our sample according to their ownership and size, and discuss state-owned, privately owned, and foreign-owned enterprises in that order. In addition, small and large firms are discussed by quarticulating firm assets. Hypothesis $\mathrm{H} 2$ is tested. 
Table 4: Regression results of different types of patent grants

\begin{tabular}{|c|c|c|c|c|c|c|}
\hline & \multicolumn{2}{|c|}{ ln (1+ Invention Grants) } & \multicolumn{2}{|c|}{ ln (1+ Design Grants) } & \multicolumn{2}{|c|}{$\begin{array}{c}\ln \\
(1+\text { Utility Model Grants })\end{array}$} \\
\hline & (1) & (2) & (3) & (4) & (5) & (6) \\
\hline Variables & OLS & OLS & OLS & OLS & OLS & OLS \\
\hline \multirow{2}{*}{ Bank3km } & $-0.000406 * * *$ & & $-0.000286 * * *$ & & $-0.00106 * * *$ & \\
\hline & $(2.29 \mathrm{e}-05)$ & & $(2.56 \mathrm{e}-05)$ & & $(4.83 \mathrm{e}-05)$ & \\
\hline \multirow[t]{2}{*}{ bank5km } & & $-0.000410 * * *$ & & $-0.000240 * * *$ & & $-0.000875 * * *$ \\
\hline & & $(2.24 \mathrm{e}-05)$ & & $(2.54 \mathrm{e}-05)$ & & $(4.87 \mathrm{e}-05)$ \\
\hline \multirow[t]{2}{*}{ Size } & $0.00444 * * *$ & $0.00449 * * *$ & $0.00476 * * *$ & $0.00480 * * *$ & $0.0179 * * *$ & $0.0180 * * *$ \\
\hline & $(0.000202)$ & $(0.000202)$ & $(0.000241)$ & $(0.000241)$ & $(0.000441)$ & $(0.000442)$ \\
\hline \multirow[t]{2}{*}{ Age } & $-0.00865 * * *$ & $-0.00868 * * *$ & $-0.00537 * * *$ & $-0.00541 * * *$ & $-0.0200 * * *$ & $-0.0201 * * *$ \\
\hline & $(0.000342)$ & $(0.000342)$ & $(0.000389)$ & $(0.000389)$ & $(0.000761)$ & $(0.000761)$ \\
\hline \multirow[t]{2}{*}{ Lever } & $-6.13 e-05^{*}$ & $-6.14 \mathrm{e}-05^{*}$ & $-3.38 e-05$ & $-3.39 \mathrm{e}-05$ & -0.000156 & -0.000157 \\
\hline & $(3.44 \mathrm{e}-05)$ & $(3.44 \mathrm{e}-05)$ & $(2.49 \mathrm{e}-05)$ & $(2.50 \mathrm{e}-05)$ & $(9.99 \mathrm{e}-05)$ & $(0.000100)$ \\
\hline \multirow[t]{2}{*}{$R O A$} & $0.00115 * * *$ & $0.00115 * * *$ & $0.00114 * * *$ & $0.00115 * * *$ & $0.00455 * * *$ & $0.00459 * * *$ \\
\hline & $(0.000415)$ & $(0.000414)$ & $(0.000392)$ & $(0.000392)$ & $(0.00151)$ & $(0.00151)$ \\
\hline \multirow[t]{2}{*}{ Fixed Asset } & $-0.00339 * * *$ & $-0.00335 * * *$ & $-0.00179 * * *$ & $-0.00176 * * *$ & $-0.00367 * * *$ & $-0.00358 * * *$ \\
\hline & $(0.000507)$ & $(0.000507)$ & $(0.000598)$ & $(0.000598)$ & $(0.00115)$ & $(0.00115)$ \\
\hline \multirow[t]{2}{*}{ Cash Flow } & $-0.00154 * * *$ & $-0.00155 * * *$ & $-0.00151 * * *$ & $-0.00152 * * *$ & $-0.00606 * * *$ & $-0.00610 * * *$ \\
\hline & $(0.000553)$ & $(0.000552)$ & $(0.000521)$ & $(0.000522)$ & $(0.00201)$ & $(0.00201)$ \\
\hline \multirow[t]{2}{*}{$\begin{array}{c}\ln (G D P \\
\text { capita }) \\
\end{array}$} & $0.00418 * * *$ & $0.00409 * * *$ & $0.00301 * *$ & $0.00282 * *$ & 0.00305 & 0.00229 \\
\hline & $(0.00115)$ & $(0.00115)$ & $(0.00135)$ & $(0.00135)$ & $(0.00230)$ & $(0.00230)$ \\
\hline \multirow[t]{2}{*}{$\begin{array}{c}\ln \\
\text { (Population) }\end{array}$} & $0.0721 * * *$ & $0.0716^{* * *}$ & $0.0694 * * *$ & $0.0692 * * *$ & $0.216^{* * *}$ & $0.215 * * *$ \\
\hline & $(0.00516)$ & $(0.00516)$ & $(0.00515)$ & $(0.00515)$ & $(0.0105)$ & $(0.0105)$ \\
\hline \multirow[t]{2}{*}{ Loan } & $-0.00343 * * *$ & $-0.00340 * * *$ & $0.00793 * * *$ & $0.00790 * * *$ & $0.0128 * * *$ & $0.0127 * * *$ \\
\hline & $(0.000648)$ & $(0.000648)$ & $(0.000855)$ & $(0.000856)$ & $(0.00140)$ & $(0.00140)$ \\
\hline \multirow[t]{2}{*}{ Industry } & $-0.101 * * *$ & $-0.102 * * *$ & $-0.0790 * * *$ & $-0.0792 * * *$ & $-0.273 * * *$ & $-0.274 * * *$ \\
\hline & $(0.00481)$ & $(0.00481)$ & $(0.00515)$ & $(0.00515)$ & $(0.0101)$ & $(0.0101)$ \\
\hline \multirow[t]{2}{*}{ Imbalance } & $9.65 \mathrm{e}-05$ & 0.000101 & $0.000485 * *$ & $0.000479 * *$ & $0.00161 * * *$ & $0.00158 * * *$ \\
\hline & $(0.000172)$ & $(0.000172)$ & $(0.000203)$ & $(0.000203)$ & $(0.000338)$ & $(0.000338)$ \\
\hline \multirow[t]{2}{*}{$F D I$} & $-0.0905 * * *$ & $-0.0913 * * *$ & $-0.0831 * * *$ & $-0.0839 * * *$ & $-0.273 * * *$ & $-0.276 * * *$ \\
\hline & $(0.0105)$ & $(0.0105)$ & $(0.0100)$ & $(0.0100)$ & $(0.0215)$ & $(0.0215)$ \\
\hline \multirow[t]{2}{*}{ Wage } & $-4.95 e-05$ & $-4.78 \mathrm{e}-05$ & $0.000226 * *$ & $0.000229 * *$ & $0.000893 * * *$ & $0.000904 * * *$ \\
\hline & $(5.17 \mathrm{e}-05)$ & $(5.17 \mathrm{e}-05)$ & $(9.19 \mathrm{e}-05)$ & $(9.19 \mathrm{e}-05)$ & $(0.000172)$ & $(0.000172)$ \\
\hline \multirow[t]{2}{*}{ Constant } & $-0.440 * * *$ & $-0.435 * * *$ & $-0.449 * * *$ & $-0.445^{* * *}$ & $-1.322 * * *$ & $-1.307 * * *$ \\
\hline & $(0.0355)$ & $(0.0355)$ & $(0.0365)$ & $(0.0365)$ & $(0.0705)$ & $(0.0705)$ \\
\hline Firm FE & Yes & Yes & Yes & Yes & Yes & Yes \\
\hline City FE & Yes & Yes & Yes & Yes & Yes & Yes \\
\hline Year FE & Yes & Yes & Yes & Yes & Yes & Yes \\
\hline No. Obs & $1,839,203$ & $1,839,203$ & $1,839,203$ & $1,839,203$ & $1,839,203$ & $1,839,203$ \\
\hline R-squared & 0.430 & 0.430 & 0.415 & 0.415 & 0.443 & 0.443 \\
\hline
\end{tabular}




\subsection{Analysis of differences in financing advantages on different types of firms}

Table 5 reports the regression results of the availability of credit resources measured by the number of bank branches around the firm on the total number of patent applications for private industrial firms, state-owned industrial firms and foreignowned industrial firms, respectively.

Observing (1)-(2) in Table 5, the regression coefficients are negative at the $1 \%$ level for private firms where located around both $3 \mathrm{~km}$ and $5 \mathrm{~km}$. Columns (3) - (6) in Table 5 show the regression results for the number of patent applications for stateowned and foreign-owned industrial enterprises. The data show that the regression coefficient is negative at the $1 \%$ significant level for banks around $3 \mathrm{~km}$ and $5 \mathrm{~km}$. By looking at the summary (1)-(6), for the number of $3 \mathrm{~km}$ banking institutions, a one standard deviation increase decreases the number of patent applications by $1.674 \%$, $1.691 \%$, and $0.777 \%$ for the different types of industrial enterprises, respectively. For the number of $5 \mathrm{~km}$ banking institutions, a one standard deviation increase decreases the number of applications by $1.246 \%, 1.849 \%$, and $1.165 \%$ for the above three types of enterprises.

The analysis of the data leads to the following conclusion: the increase in the availability of credit resources has a dampening effect on the total number of patent applications by private, state-owned and foreign-owned industrial enterprises. 
Table 5: Regression result of numbers of patent application in different types of firms

\begin{tabular}{|c|c|c|c|c|c|c|}
\hline & \multicolumn{2}{|c|}{ Ln (1+Applications) } & \multicolumn{2}{|c|}{ Ln (1+Applications) } & \multicolumn{2}{|c|}{ Ln (1+Applications) } \\
\hline & $\begin{array}{c}(1) \\
\text { Private }\end{array}$ & $\begin{array}{c}(2) \\
\text { Private }\end{array}$ & $\begin{array}{c}\text { (3) } \\
\text { State }\end{array}$ & $\begin{array}{c}(4) \\
\text { State }\end{array}$ & $\begin{array}{c}(5) \\
\text { Foreign }\end{array}$ & $\begin{array}{c}(6) \\
\text { Foreign }\end{array}$ \\
\hline Variables & OLS & OLS & OLS & OLS & OLS & OLS \\
\hline \multirow[t]{2}{*}{ Bank3km } & $-0.00199 * * *$ & & $-0.00201 * * *$ & & $-0.000924 * * *$ & \\
\hline & $(8.59 \mathrm{e}-05)$ & & $(0.000486)$ & & $(0.000242)$ & \\
\hline \multirow[t]{2}{*}{ bank $5 \mathrm{~km}$} & & $-0.00155^{* * *} *$ & & $-0.00210 * * *$ & & $-0.00145 * * *$ \\
\hline & & $(8.82 \mathrm{e}-05)$ & & $(0.000524)$ & & $(0.000292)$ \\
\hline \multirow[t]{2}{*}{ Size } & $0.0344 * * *$ & $0.0346^{* * *}$ & $0.0733 * * *$ & $0.0735^{* * *}$ & $0.0576^{* * *}$ & $0.0577 * * *$ \\
\hline & $(0.000795)$ & $(0.000796)$ & $(0.00534)$ & $(0.00535)$ & $(0.00245)$ & $(0.00245)$ \\
\hline \multirow[t]{2}{*}{ Age } & $-0.0223 * * *$ & $-0.0226 * * *$ & $0.0194 * * *$ & $0.0192 * * *$ & $0.0111 * * *$ & $0.0113 * * *$ \\
\hline & $(0.00136)$ & $(0.00136)$ & $(0.00660)$ & $(0.00660)$ & $(0.00407)$ & $(0.00407)$ \\
\hline \multirow[t]{2}{*}{ Lever } & $-9.25 e-06$ & $-9.98 \mathrm{e}-06$ & 0.00179 & 0.00178 & -0.00396 & -0.00389 \\
\hline & $(8.73 \mathrm{e}-05)$ & $(8.82 \mathrm{e}-05)$ & $(0.00309)$ & $(0.00310)$ & $(0.00374)$ & $(0.00374)$ \\
\hline \multirow[t]{2}{*}{$R O A$} & $0.00287 * *$ & $0.00293 * *$ & $0.0281 * *$ & $0.0283 * *$ & $0.0149 * *$ & $0.0149 * *$ \\
\hline & $(0.00132)$ & $(0.00132)$ & $(0.0121)$ & $(0.0121)$ & $(0.00595)$ & $(0.00592)$ \\
\hline \multirow[t]{2}{*}{ Fixed Asset } & $-0.0135 * * *$ & $-0.0134 * * *$ & $0.0875 * * *$ & $0.0880 * * *$ & 0.00782 & 0.00803 \\
\hline & $(0.00221)$ & $(0.00221)$ & $(0.0136)$ & $(0.0136)$ & $(0.00670)$ & $(0.00670)$ \\
\hline \multirow[t]{2}{*}{ Cash Flow } & $-0.00355 * *$ & $-0.00363 * *$ & $-0.0266 * *$ & $-0.0268 * *$ & $-0.0156 * *$ & $-0.0155^{* *}$ \\
\hline & $(0.00173)$ & $(0.00174)$ & $(0.0121)$ & $(0.0121)$ & $(0.00668)$ & $(0.00665)$ \\
\hline \multirow[t]{2}{*}{$\ln (G D P$ capita $)$} & $-0.0267 * * *$ & $-0.0282 * * *$ & $-0.0280 *$ & $-0.0285^{*}$ & $-0.0309 * * *$ & $-0.0306 * * *$ \\
\hline & $(0.00433)$ & $(0.00433)$ & $(0.0168)$ & $(0.0168)$ & $(0.00596)$ & $(0.00595)$ \\
\hline \multirow[t]{2}{*}{$\ln$ (Population) } & $0.378 * * *$ & $0.377 * * *$ & $0.632 * * *$ & $0.634 * * *$ & $-0.0912 * * *$ & $-0.0968 * * *$ \\
\hline & $(0.0203)$ & $(0.0203)$ & $(0.0962)$ & $(0.0962)$ & $(0.0287)$ & $(0.0288)$ \\
\hline \multirow[t]{2}{*}{ Loan } & $0.0413 * * *$ & $0.0411 * * *$ & 0.00511 & 0.00515 & $0.0517 * * *$ & $0.0523 * * *$ \\
\hline & $(0.00283)$ & $(0.00283)$ & $(0.0109)$ & $(0.0109)$ & $(0.00684)$ & $(0.00684)$ \\
\hline \multirow[t]{2}{*}{ Industry } & $-0.343 * * *$ & $-0.344 * * *$ & $-0.362 * * *$ & $-0.362 * * *$ & $-0.115 * * *$ & $-0.116 * * *$ \\
\hline & $(0.0188)$ & $(0.0188)$ & $(0.0806)$ & $(0.0806)$ & $(0.0400)$ & $(0.0400)$ \\
\hline \multirow[t]{2}{*}{ Imbalance } & 0.000736 & 0.000684 & $-0.00394 *$ & $-0.00399 * *$ & -0.00157 & -0.00141 \\
\hline & $(0.000689)$ & $(0.000689)$ & $(0.00203)$ & $(0.00203)$ & $(0.00393)$ & $(0.00394)$ \\
\hline \multirow[t]{2}{*}{$F D I$} & $-0.870 * * *$ & $-0.877 * * *$ & -0.322 & -0.327 & -0.115 & -0.120 \\
\hline & $(0.0445)$ & $(0.0445)$ & $(0.243)$ & $(0.243)$ & $(0.0820)$ & $(0.0820)$ \\
\hline \multirow[t]{2}{*}{ Wage } & $0.00145^{* * *}$ & $0.00147 * * *$ & -0.00175 & -0.00175 & 0.00151 & 0.00151 \\
\hline & $(0.000269)$ & $(0.000269)$ & $(0.00190)$ & $(0.00190)$ & $(0.00118)$ & $(0.00118)$ \\
\hline \multirow[t]{2}{*}{ Constant } & $-2.073 * * *$ & $-2.046 * * *$ & $-4.095 * * *$ & $-4.094 * * *$ & $0.372 * *$ & $0.414 * *$ \\
\hline & $(0.135)$ & $(0.135)$ & $(0.614)$ & $(0.614)$ & $(0.183)$ & $(0.183)$ \\
\hline Firm FE & Yes & Yes & Yes & Yes & Yes & Yes \\
\hline City FE & Yes & Yes & Yes & Yes & Yes & Yes \\
\hline Year FE & Yes & Yes & Yes & Yes & Yes & Yes \\
\hline No. Obs & $1,376,445$ & $1,376,445$ & 88,536 & 88,536 & 272,328 & 272,328 \\
\hline R-squared & 0.518 & 0.518 & 0.673 & 0.673 & 0.558 & 0.558 \\
\hline
\end{tabular}


Table 6 reports the regression results of the availability of credit resources measured by the number of bank branches around the firm on the total number of patents granted for private, state-owned and foreign-owned industrial firms, respectively. Observing (1)-(2) in Table 5, the regression coefficients are negative at the $1 \%$ significant level for private firms where located around $3 \mathrm{~km}$ and $5 \mathrm{~km}$. Columns (3) - (6) of Table 5 show the regression results of the number of patent applications for state-owned and foreign-owned industrial enterprises. The data show that the regression coefficient is significantly negative at the $1 \%$ level for bank in $3 \mathrm{~km}$ and $5 \mathrm{~km}$. By looking at the summary (1)-(6), for the number of $3 \mathrm{~km}$ banking institutions, a one standard deviation increase decreases the number of patent applications by $0.951 \%, 1.817 \%$, and $0.777 \%$ for the different types of industrial enterprises, respectively. For the number of $5 \mathrm{~km}$ banking institutions, a one standard deviation increase decreases the number of licenses by $0.719 \%, 1.688 \%$, and $1.205 \%$ for the above three types of enterprises.

The analysis of the data leads to the following conclusion: the increase in the availability of credit resources has a dampening effect on the total number of patents granted by private, state-owned and foreign-owned industrial enterprises.

In addition, the results in Tables 5 and 6 show that the inhibitory effect of the number of bank branches in the vicinity of the enterprise on innovation activity is more pronounced in SOEs, both within $3 \mathrm{~km}$ and $5 \mathrm{~km}$. The absolute values of the regression coefficients of the core explanatory variables $B a n k 3 \mathrm{~km}$ and $B a n k 5 \mathrm{~km}$ in the SOE sample are significantly larger than those of private and foreign enterprises, and the coefficients are significantly negative in SOEs. The coefficients of Bank3km and Bank5km are significantly larger in absolute value than those of private and foreign enterprises. Since SOEs have more stable assets and projects, and are supported by government policies, they have higher access to financing than other types of companies. Therefore, the inhibitory effect of credit resource availability on innovation ability is more pronounced among SOEs. 
Table 6: Regression result of numbers of patent grants in different types of firms

\begin{tabular}{|c|c|c|c|c|c|c|}
\hline & \multicolumn{2}{|c|}{ In (1+ Invention Grants) } & \multicolumn{2}{|c|}{ In (1+ Invention Grants) } & \multicolumn{2}{|c|}{ In (1+ Invention Grants) } \\
\hline & (1) & (2) & (3) & (4) & (5) & (6) \\
\hline & Private & Private & State & State & Foreign & Foreign \\
\hline Variables & OLS & OLS & OLS & OLS & OLS & OLS \\
\hline \multirow[t]{2}{*}{ Bank $3 \mathrm{~km}$} & $-0.00113 * * *$ & & $-0.00216^{* * *}$ & & $-0.00166 * * *$ & \\
\hline & $(5.87 e-05)$ & & $(0.000412)$ & & $(0.000178)$ & \\
\hline \multirow[t]{2}{*}{ bank $5 \mathrm{~km}$} & & $-0.000866 * * *$ & & $-0.00230 * * *$ & & $-0.00172 * * *$ \\
\hline & & $(5.84 \mathrm{e}-05)$ & & $(0.000435)$ & & $(0.000213)$ \\
\hline \multirow[t]{2}{*}{ Size } & $0.0186 * * *$ & $0.0188 * * *$ & $0.0591 * * *$ & $0.0593 * * *$ & $0.0433 * * *$ & $0.0435 * * *$ \\
\hline & $(0.000540)$ & $(0.000541)$ & $(0.00447)$ & $(0.00447)$ & $(0.00183)$ & $(0.00184)$ \\
\hline \multirow[t]{2}{*}{ Age } & $-0.0292 * * *$ & $-0.0294 * * *$ & -0.00676 & -0.00690 & $-0.0185 * * *$ & $-0.0184 * * *$ \\
\hline & $(0.000924)$ & $(0.000924)$ & $(0.00576)$ & $(0.00575)$ & $(0.00304)$ & $(0.00304)$ \\
\hline \multirow[t]{2}{*}{ Lever } & $-0.000222^{*}$ & $-0.000222 *$ & 0.000485 & 0.000469 & $-0.0131 * * *$ & $-0.0131 * * *$ \\
\hline & $(0.000132)$ & $(0.000132)$ & $(0.00342)$ & $(0.00343)$ & $(0.00274)$ & $(0.00274)$ \\
\hline \multirow[t]{2}{*}{$R O A$} & $0.00423 * *$ & $0.00427 * *$ & $0.0456 * * *$ & $0.0458 * * *$ & $0.0106 * *$ & $0.0106 * *$ \\
\hline & $(0.00174)$ & $(0.00174)$ & $(0.0115)$ & $(0.0115)$ & $(0.00479)$ & $(0.00478)$ \\
\hline \multirow[t]{2}{*}{ Fixed Asset } & $-0.0105 * * *$ & $-0.0104 * * *$ & $0.0551 * * *$ & $0.0557 * * *$ & $0.0156 * * *$ & $0.0161 * * *$ \\
\hline & $(0.00142)$ & $(0.00142)$ & $(0.0105)$ & $(0.0105)$ & $(0.00468)$ & $(0.00468)$ \\
\hline \multirow{2}{*}{ Cash Flow } & $-0.00606 * * *$ & $-0.00611 * * *$ & $-0.0487 * * *$ & $-0.0489 * * *$ & $-0.0123^{* *}$ & $-0.0122 * *$ \\
\hline & $(0.00224)$ & $(0.00224)$ & $(0.0113)$ & $(0.0113)$ & $(0.00511)$ & $(0.00509)$ \\
\hline \multirow[t]{2}{*}{$\ln ($ GDP capita $)$} & $0.0245^{* * *}$ & $0.0236 * * *$ & $-0.0341 * *$ & $-0.0345 * *$ & $-0.0225 * * *$ & $-0.0230 * * *$ \\
\hline & $(0.00341)$ & $(0.00341)$ & $(0.0141)$ & $(0.0142)$ & $(0.00516)$ & $(0.00517)$ \\
\hline \multirow[t]{2}{*}{$\ln$ (Population) } & $0.308 * * *$ & $0.307 * * *$ & $0.555^{* * *}$ & $0.556 * * *$ & $0.0922 * * *$ & $0.0877 * * *$ \\
\hline & $(0.0138)$ & $(0.0138)$ & $(0.0780)$ & $(0.0780)$ & $(0.0232)$ & $(0.0233)$ \\
\hline \multirow[t]{2}{*}{ Loan } & $0.0162 * * *$ & $0.0160^{* * *}$ & $-0.0165^{*}$ & $-0.0164 *$ & $0.0375^{* * *}$ & $0.0376^{* * *}$ \\
\hline & $(0.00187)$ & $(0.00187)$ & $(0.00851)$ & $(0.00851)$ & $(0.00479)$ & $(0.00479)$ \\
\hline \multirow[t]{2}{*}{ Industry } & $-0.431 * * *$ & $-0.432 * * *$ & -0.577 *** & $-0.577 * * *$ & $-0.142 * * *$ & $-0.145 * * *$ \\
\hline & $(0.0133)$ & $(0.0134)$ & $(0.0683)$ & $(0.0683)$ & $(0.0306)$ & $(0.0306)$ \\
\hline \multirow[t]{2}{*}{ Imbalance } & $0.00195 * * *$ & $0.00191 * * *$ & $-0.00317^{*}$ & $-0.00322 *$ & $0.00684 * *$ & $0.00676^{* *}$ \\
\hline & $(0.000455)$ & $(0.000455)$ & $(0.00166)$ & $(0.00166)$ & $(0.00268)$ & $(0.00268)$ \\
\hline \multirow[t]{2}{*}{$F D I$} & $-0.481 * * *$ & $-0.485^{* * *}$ & $-0.387 *$ & $-0.393^{*}$ & 0.0650 & 0.0591 \\
\hline & $(0.0281)$ & $(0.0281)$ & $(0.203)$ & $(0.203)$ & $(0.0594)$ & $(0.0594)$ \\
\hline \multirow[t]{2}{*}{ Wage } & $0.00112 * * *$ & $0.00114 * * *$ & $-0.00205^{*}$ & $-0.00205^{*}$ & $0.00192 *$ & 0.00193* \\
\hline & $(0.000199)$ & $(0.000199)$ & $(0.00114)$ & $(0.00114)$ & $(0.00102)$ & $(0.00102)$ \\
\hline \multirow[t]{2}{*}{ Constant } & $-2.014 * * *$ & $-1.998^{* * *}$ & $-3.271 * * *$ & $-3.269 * * *$ & $-0.649 * * *$ & $-0.608 * * *$ \\
\hline & $(0.0967)$ & $(0.0966)$ & $(0.502)$ & $(0.502)$ & $(0.152)$ & $(0.152)$ \\
\hline Firm FE & Yes & Yes & Yes & Yes & Yes & Yes \\
\hline City FE & Yes & Yes & Yes & Yes & Yes & Yes \\
\hline Year FE & Yes & Yes & Yes & Yes & Yes & Yes \\
\hline Observations & $1,376,445$ & $1,376,445$ & 88,536 & 88,536 & 272,328 & 272,328 \\
\hline R-squared & 0.473 & 0.473 & 0.601 & 0.601 & 0.509 & 0.509 \\
\hline
\end{tabular}




\subsection{Analysis based on industry firms of different sizes}

Table 7 reports the regression results of credit resource availability measured by the number of bank branches around the firm on the total number of patent applications for large and small industrial firms, respectively.

Observing (1)-(4) in Table 7, the regression coefficients for banks within $3 \mathrm{~km}$ are negative at the $1 \%$ significant level for both small and large firms. However, for small industrial firms within $5 \mathrm{~km}$ it is significantly negative at the $10 \%$ level. By looking at the summary (1)-(4), an increase of one standard deviation of 8.414 for the number of banking institutions within $3 \mathrm{~km}$ decreases the number of patent applications by $0.231 \%$ for small and $1.405 \%$ for large industrial firms, respectively, and an increase of one standard deviation of 8.037 for the number of banking institutions within $5 \mathrm{~km}$ decreases the number of applications by $0.131 \%$ and $1.013 \%$ for both types of firms.

The analysis of the data leads to the following conclusion: the increase in the availability of credit resources has a negative effect on the total number of patent applications for small and large industrial firms.

Table 8 reports the regression results of the availability of credit resources measured by the number of bank branches around the firm on the total number of patents granted for large and small industrial firms, respectively.

Observing (1)-(2) in Table 8, the regression coefficients are not significantly negative for small industrial firms, while columns (3)-(4) show that the regression coefficients for large firms are significantly negative at the $1 \%$ level. By summarizing (1)-(4), an increase of one standard deviation of 8.414 for the number of banking institutions at $3 \mathrm{~km}$ decreases the number of patents granted for small and large industrial firms by $0.038 \%$ and $1.481 \%$, respectively. An increase of one standard deviation of 8.037 for the number of banking institutions at $5 \mathrm{~km}$ decreases the number of patents granted for both types of firms by $0.032 \%$ and $0.964 \%$.

The analysis of the data leads to the following conclusions: the increase in the availability of credit resources has a negative effect on the total number of patents granted by small and large industrial firms. The inhibitory effect of credit availability on firms' innovation activity is more pronounced in large firms. Because large firms have relatively more access to financing, bank investment is also skewed toward large industrial firms with high quality assets. Therefore, hypothesis $\mathrm{H} 2$ is verified that the effect of credit availability on firms' innovation activity is indeed heterogeneous in terms of financing advantage, and this negative effect is more pronounced in SOEs and large firms than in non-SOEs and SMEs. 
Table 7: Regression result of numbers of patent applications in different size of firms

\begin{tabular}{|c|c|c|c|c|}
\hline & \multicolumn{2}{|c|}{$\ln (1+$ Applications $)$} & \multicolumn{2}{|c|}{$\ln (1+$ Applications $)$} \\
\hline & (1) & (2) & (3) & (4) \\
\hline Variables & Small & Small & Large & Large \\
\hline \multirow[t]{2}{*}{ Bank3km } & $-0.000275^{* * *}$ & & $-0.00167 * * *$ & \\
\hline & $(7.90 \mathrm{e}-05)$ & & $(0.000232)$ & \\
\hline \multirow[t]{2}{*}{ bank $5 \mathrm{~km}$} & & $-0.000156^{*}$ & & $-0.00126 * * *$ \\
\hline & & $(8.25 \mathrm{e}-05)$ & & $(0.000254)$ \\
\hline \multirow[t]{2}{*}{ Size } & $0.00445 * * *$ & $0.00446 * * *$ & $0.139 * * *$ & $0.140 * * *$ \\
\hline & (0.000892) & $(0.000892)$ & $(0.00329)$ & $(0.00329)$ \\
\hline \multirow[t]{2}{*}{ Age } & -0.000434 & -0.000436 & $-0.00796 * *$ & $-0.00827 * *$ \\
\hline & $(0.000840)$ & $(0.000840)$ & $(0.00394)$ & $(0.00394)$ \\
\hline \multirow[t]{2}{*}{ Lever } & $3.92 \mathrm{e}-05$ & $3.92 \mathrm{e}-05$ & $-0.0277 * * *$ & $-0.0278 * * *$ \\
\hline & $(3.59 \mathrm{e}-05)$ & $(3.58 \mathrm{e}-05)$ & $(0.00609)$ & $(0.00610)$ \\
\hline \multirow[t]{2}{*}{$R O A$} & -0.000517 & -0.000515 & $0.0951 * * *$ & $0.0949 * * *$ \\
\hline & $(0.000997)$ & $(0.000996)$ & $(0.0179)$ & $(0.0179)$ \\
\hline \multirow[t]{2}{*}{ Fixed Asset } & $0.00409 *$ & $0.00409 *$ & $0.0336 * * *$ & $0.0341 * * *$ \\
\hline & $(0.00215)$ & $(0.00215)$ & $(0.00702)$ & $(0.00702)$ \\
\hline \multirow[t]{2}{*}{ Cash Flow } & 0.000760 & 0.000757 & $-0.0407 * *$ & $-0.0407 * *$ \\
\hline & $(0.00133)$ & $(0.00133)$ & $(0.0175)$ & $(0.0175)$ \\
\hline \multirow[t]{2}{*}{$\ln ($ GDP capita $)$} & $0.00734 * *$ & $0.00711 * *$ & $-0.0519 * * *$ & $-0.0532 * * *$ \\
\hline & $(0.00353)$ & $(0.00353)$ & $(0.00691)$ & $(0.00691)$ \\
\hline \multirow[t]{2}{*}{$\ln$ (Population) } & 0.0266 & 0.0265 & $0.365 * * *$ & $0.363 * * *$ \\
\hline & $(0.0294)$ & $(0.0294)$ & $(0.0380)$ & $(0.0380)$ \\
\hline \multirow[t]{2}{*}{ Loan } & $0.00416 * *$ & $0.00408 * *$ & $0.0553 * * *$ & $0.0550 * * *$ \\
\hline & $(0.00193)$ & $(0.00193)$ & $(0.00750)$ & $(0.00750)$ \\
\hline \multirow[t]{2}{*}{ Industry } & $-0.0834 * * *$ & $-0.0832 * * *$ & $-0.118 * * *$ & $-0.117 * * *$ \\
\hline & $(0.0179)$ & $(0.0179)$ & $(0.0422)$ & $(0.0422)$ \\
\hline \multirow[t]{2}{*}{ Imbalance } & $0.000743^{*}$ & $0.000736 *$ & 0.00192 & 0.00180 \\
\hline & $(0.000435)$ & $(0.000434)$ & $(0.00179)$ & $(0.00179)$ \\
\hline \multirow[t]{2}{*}{$F D I$} & $-0.102 * * *$ & $-0.102 * * *$ & $-0.755 * * *$ & $-0.758 * * *$ \\
\hline & $(0.0365)$ & $(0.0365)$ & $(0.112)$ & $(0.112)$ \\
\hline \multirow[t]{2}{*}{ Wage } & 0.000799 & 0.000809 & 0.000638 & 0.000649 \\
\hline & $(0.000741)$ & $(0.000741)$ & $(0.000493)$ & $(0.000493)$ \\
\hline \multirow[t]{2}{*}{ Constant } & -0.226 & -0.224 & $-3.051 * * *$ & $-3.029 * * *$ \\
\hline & $(0.185)$ & $(0.185)$ & $(0.245)$ & $(0.244)$ \\
\hline Firm FE & Yes & Yes & Yes & Yes \\
\hline City FE & Yes & Yes & Yes & Yes \\
\hline Year FE & Yes & Yes & Yes & Yes \\
\hline No. Obs & 378,364 & 378,364 & 463,280 & 463,280 \\
\hline R-squared & 0.462 & 0.462 & 0.599 & 0.599 \\
\hline
\end{tabular}


Table 8: Regression result of numbers of patent grants in different size of firms

\begin{tabular}{|c|c|c|c|c|}
\hline & \multicolumn{2}{|c|}{ ln (1+Grants) } & \multicolumn{2}{|c|}{ ln (1+Grants) } \\
\hline & (1) & (2) & (3) & (4) \\
\hline Variables & Small & Small & Large & Large \\
\hline \multirow[t]{2}{*}{ Bank3km } & -0.00004 .52 & & $-0.00176 * * *$ & \\
\hline & $(3.08 \mathrm{e}-05)$ & & $(0.000177)$ & \\
\hline \multirow[t]{2}{*}{ bank5 $\mathrm{km}$} & & -0.00004 .02 & & $-0.00120 * * *$ \\
\hline & & $(3.12 \mathrm{e}-05)$ & & $(0.000189)$ \\
\hline \multirow[t]{2}{*}{ Size } & $0.00118 * * *$ & $0.00119 * * *$ & $0.122 * * *$ & $0.122 * * *$ \\
\hline & $(0.000382)$ & $(0.000382)$ & $(0.00256)$ & $(0.00256)$ \\
\hline \multirow[t]{2}{*}{ Age } & -0.000135 & -0.000134 & $-0.0399 * * *$ & $-0.0403 * * *$ \\
\hline & $(0.000392)$ & $(0.000392)$ & $(0.00306)$ & $(0.00306)$ \\
\hline \multirow[t]{2}{*}{ Lever } & $2.10 \mathrm{e}-05$ & $2.10 \mathrm{e}-05$ & $-0.0507 * * *$ & $-0.0507 * * *$ \\
\hline & $(1.79 \mathrm{e}-05)$ & $(1.79 \mathrm{e}-05)$ & $(0.00480)$ & $(0.00480)$ \\
\hline \multirow[t]{2}{*}{$R O A$} & -0.000469 & -0.000469 & $0.0457 * *$ & $0.0455 * *$ \\
\hline & $(0.000504)$ & $(0.000504)$ & $(0.0180)$ & $(0.0179)$ \\
\hline \multirow[t]{2}{*}{ Fixed Asset } & 0.00105 & 0.00105 & $0.0298 * * *$ & $0.0304 * * *$ \\
\hline & $(0.000934)$ & $(0.000933)$ & $(0.00518)$ & $(0.00518)$ \\
\hline \multirow[t]{2}{*}{ Cash Flow } & 0.000639 & 0.000639 & $-0.0459 * *$ & $-0.0459 * *$ \\
\hline & $(0.000665)$ & $(0.000665)$ & $(0.0184)$ & $(0.0184)$ \\
\hline \multirow[t]{2}{*}{$\ln ($ GDP capita $)$} & -0.00122 & -0.00123 & -0.00542 & -0.00710 \\
\hline & $(0.00205)$ & $(0.00204)$ & $(0.00592)$ & $(0.00593)$ \\
\hline \multirow[t]{2}{*}{$\ln$ (Population) } & $0.0314 * *$ & $0.0314 * *$ & $0.448 * * *$ & $0.446 * * *$ \\
\hline & $(0.0159)$ & $(0.0159)$ & $(0.0294)$ & $(0.0294)$ \\
\hline \multirow[t]{2}{*}{ Loan } & 0.00110 & 0.00110 & $0.0271 * * *$ & $0.0266 * * *$ \\
\hline & $(0.000766)$ & $(0.000765)$ & $(0.00550)$ & $(0.00550)$ \\
\hline \multirow[t]{2}{*}{ Industry } & $-0.0235 * * *$ & $-0.0235 * * *$ & $-0.427 * * *$ & $-0.426 * * *$ \\
\hline & $(0.00820)$ & $(0.00820)$ & $(0.0334)$ & $(0.0334)$ \\
\hline \multirow[t]{2}{*}{ Imbalance } & 0.000210 & 0.000211 & 0.00150 & 0.00134 \\
\hline & $(0.000166)$ & $(0.000166)$ & $(0.00136)$ & $(0.00137)$ \\
\hline \multirow[t]{2}{*}{$F D I$} & -0.000955 & -0.000984 & $-0.572 * * *$ & $-0.576 * * *$ \\
\hline & $(0.0111)$ & $(0.0111)$ & $(0.0828)$ & $(0.0828)$ \\
\hline \multirow[t]{2}{*}{ Wage } & 0.000312 & 0.000312 & 0.000333 & 0.000347 \\
\hline & $(0.000265)$ & $(0.000265)$ & $(0.000397)$ & $(0.000397)$ \\
\hline \multirow[t]{2}{*}{ Constant } & $-0.179 *$ & $-0.179 *$ & $-3.684 * * *$ & $-3.660 * * *$ \\
\hline & $(0.103)$ & $(0.103)$ & $(0.193)$ & $(0.193)$ \\
\hline Firm FE & Yes & Yes & Yes & Yes \\
\hline City FE & Yes & Yes & Yes & Yes \\
\hline Year FE & Yes & Yes & Yes & Yes \\
\hline Observations & 378,364 & 378,364 & 463,280 & 463,280 \\
\hline R-squared & 0.429 & 0.429 & 0.551 & 0.551 \\
\hline
\end{tabular}




\section{Conclusion}

This paper examines the impact of the financial geography of credit resource supply on the number of patents of industrial enterprises at the micro level, using the number of bank branches around the enterprise as a proxy for the availability of credit resources. The empirical results show that: first, the richer the availability of credit resources, represented by the number of bank branches around the enterprise, the lower the number of industrial enterprise patents; second, the results based on the difference of enterprise financing advantages show that the inhibitory effect of credit resource availability on enterprise innovation activities is more obvious in the sample of state-owned enterprises and large enterprises with financing advantages, while the inhibitory effect is weaker for non-state-owned enterprises and SMEs. This suggests that the inhibitory effect of credit resources on corporate innovation is a structural imbalance based on the mismatch of financial resources.

The findings of this paper have the following implications for China's financial supply reform: First, to prevent the negative impact of financial resource mismatch on the real economy and corporate innovation. A reasonable supply of credit resources can promote the innovation activities of enterprises, but a structural imbalance in the supply of credit resources can also have a negative effect on the number of industrial enterprises' patents. Scientific and reasonable bank network appropriation and financial resource layout should be promoted to prevent the negative effects of financial resource mismatch and financial resource overload on the real economy. Second, optimize the layout of bank network, guide all kinds of banks to improve the quality and efficiency of service to the real economy. On the one hand, resolutely stop the bunching establishment and disorderly expansion of bank network and prevent too many network institutions from piling up in some areas or around individual enterprises, thus inhibiting the number of industrial enterprise patents. Continuously improve the quality and efficiency of service to the real economy, actively support the R\&D and innovation activities of enterprises and help them transform and upgrade and the high-quality development of the regional economy. Third, China's supply-side reform lies first and foremost in financial supply-side reform. Finance is the focus of the modern economy. Its resource allocation efficiency largely determines the quality of a country's economic development. Indirect financing, mainly bank credit, accounts for more than $80 \%$ of total social financing in China. The liability side of commercial banks (deposits, loans or debt issuance) has the requirement of "rigid exchange", so they also prefer "rigid exchange" assets in credit allocation and asset allocation on the asset side, which leads to the natural aversion to risk and uncertainty in commercial banks' indirect financing and credit allocation. This has led to the fact that commercial banks' indirect financing and credit allocation are naturally risk averse and uncertainty averse. When most of the financial resources of the whole society are allocated to assets with "rigid" properties, such as state-owned enterprises, government infrastructure and real estate, through the commercial banking system, the number of patents of industrial enterprises will decrease. It is the R\&D and 
innovation ability of industrial enterprises represented by the number of patents that is the source and driving force for the transformation, upgrading and high-quality development of regions and enterprises. The imbalance of financing structure ratio will lead to the mismatch of financial resources, and the mismatch of financial resources will lead to the lack of innovation power of the whole society. Therefore, China's supply-side reform should first promote financial supply-side reform, actively guide financial institutions to serve the real economy, alleviate the financing constraints of private enterprises and small and medium-sized enterprises, promote the transformation of the financial sector from indirect financing, which prefers "rigid" assets, to direct financing, which is more entrepreneurial, and guide and stimulate the financial sector to support the R\&D and innovation of micro enterprises. This will lead the financial sector to support the R\&D innovation and transformation and upgrading of micro-enterprise entities and promote the highquality development of China's financial and real economy.

\section{References}

[1] Chen Shihua, Lu Changchong, Jiang Guangsheng \& Wang Yaru. (2015). The Impact of Political Promotion of SOE Executives on Corporate M\&A Behavior-An Empirical Study Based on the Theory of Corporate Growth Pressure. Management World, 000(009), 125-136.

[2] Cai Jing \& Dong Yan. (2016). Banking Competition and Firm Innovation Empirical Evidence from Chinese Industrial Firms. Financial Research Journal, 000(011), 96-111.

[3] Ji Zhihong. (2014). Study of Regional Differences in Deposit-Loan RatioBased on Commercial Bank Branch Data. Financial Research Journal, 05, 12 31.

[4] Lu Zhengfei, He Jie \& Dou Huang. (2015). Who is more over-indebted: stateowned or non-state-owned enterprises? Financial Research Journal, 050(012), 54-67.

[5] Liu Ruiming. (2011). Financial Repression, Ownership Discrimination and Growth Drag. A Re-Examination of Efficiency Losses of State-Owned Enterprises. China Economic Quarterly, 010(001), 603-618.

[6] Tang Qingquan \& Wu Cen. (2015). Banking Sector Structure and Financing Constraints on Corporate Activities. Financial Research Journal, 421(07), 116134.

[7] Yi Gang. (2019). Brilliant Achievements in Finance in the 70th Year of the Founding of New China. China Financial, 19.

[8] Yao Yaojun. (2012). Financial Development and Entrepreneurship: Empirical Evidence from Provincial Panel Data in China. Journal of Financial Development Research, (05), 3-7.

[9] Zhang Jianhua, Wang Peng \& Feng Genfu. (2016). Banking Structure and Total Factor Productivity. An Empirical Research Based on Chinese 
Commercial Banks Data and Hyperbolic Distance Function. Financial Research Journal, (11), 114-128.

[10] Zhang Shuoxuan \& Du Xu. (2019). Bank Availability and Corporate Financing: Mechanism and Heterogeneity Analysis. Management Review, 5.

[11] Allen, N. B., Nathan H. M., Mitchell A. P., Raghuram G. R. \& Jeremy C. S., (2005). Does Function Follow Organizational Form? Evidence From the Lending Practices of Large and Small Banks. Journal of Financial Economics, 76, 237-269.

[12] Agarwal, S. \& Hauswald R. (2010). Distance and Private Information in Lending. Review of Financial Studies, 23, 2757-2788.

[13] Alessandrini, P. A., Presbitero F. \& Zazzaro A., (2009). Banks Distances and Firms' Financing Constraints. Review of Finance, 13, 261-307.

[14] Bester, H., (1985). Screening vs Rationing in Credit Markets with Imperfect Information. American Economic Review, 75, 850-855.

[15] Benfratello, L., Schiantarelli F. \& Sembenelli A. (2008). Banks and Innovation: Microeconometric: Evidence on Italian Firms. Journal of Financial Economics, 90, 197-217.

Berger, A. \& Udell G. (2006). A More Complete Conceptual Framework for SME Finance, Journal of Banking and Finance, 30, 2945 -2966.

[16] Degryse, H. \& Ongena S. (2005). Distance, Lending Relationships, and Competition. Journal of Finance, 60, 231-266.

[17] Degryse, H. \& Ongena S. (2007). The Impact of Competition on Bank Orientation. Journal of Financial Intermediation,16, 399-424 .

[18] Favara, F., Morellec, E., Schroth, E \& Valta, P. (2017). Debt Enforcement, Investment, and Risk Taking Across Countries. Journal of Financial Economic, 123, 22-41.

[19] Guiso, L., P. Sapienza. \& L. Zingales. (2004). Does local financial development matter? Quarterly Journal of Economics, 119, 929 -969.

[20] Hollander, S. \& A. Verriest. (2016). Bridging the Gap: the Design of Bank Loan Contracts and Distance. Journal of Financial Economics,11, 399-419.

[21] Heaton, J. B. (2002) Managerial Optimism and Corporate Finance, Financial Management, 31, 33-46.

[22] Miao, J., \& P. Wang. (2014). Sectoral Bubbles, Misallocation and Endogenous Growth. Journal of Mathematical Economics, 53, 153-163.

[23] Pfeffer, J., \& G. R. Salancik. (1979). The External Control of Organizations: A Resource Dependence Perspective. Economic Journal, 23, 399- 424.

[24] Richardson, S. (2006). Over-investment of Free Cash Flow. Review of Accounting Studies, 11, 159-189.

[25] Xiao, S., \& S. Zhao. (2012). Financial Development Government Ownership of Banks and Firm Innovation. Journal of International Money and Finance, $31,880-90$ 